This is the peer reviewed version of the following article: Slatter R. Materialities and historical geographies: An introduction. Area. 2019;51:2-6, which has been published in final form at https://doi.org/10.1111/ area.12518. This article may be used for non-commercial purposes in accordance with Wiley Terms and Conditions for Use of Self-Archived Versions.

\title{
Materialities and Historical Geographies: an introduction
}

\section{Ruth Slatter}

\section{Abstract}

While (historical) geographers are now increasingly engaging with material things and approaches, there has been little debate about the role and place of material sources and methodologies within historical geography research. This special section of Area draws together five papers in which historical geographers explore material sources and the application of material approaches in order to make conceptual, methodological and empirical contributions to (historical) geography. These papers demonstrate the potential range of possibilities available to geographers (historical or not) attuned to the materiality of space and encourage further discussion about the relationship between material cultures and geographical research. This introductory editorial outlines the impetus for this special section. It reflects on how material culture has already been used within geographical research, considers why there is a need to debate (specifically historical) geographers' engagement with materiality in greater depth, and suggests some ways in which the papers in this special section have already contributed to this debate.

Key words: materiality, material cultures, historical geography, methodology 
Material cultures have long been identified as potentially useful sources for historical, geographical, sociological and anthropological studies. But what exactly can material cultures offer historical geography, and by implication geographical research more generally? What material things can be used within these studies and do they usefully contribute to geographical research? The papers in this special section will directly respond to these questions. Their starting point has been the very broadest definition of material cultures, embracing objects, things, ephemera, buildings, urban and rural landscapes, the natural and the man made, the animate and the inanimate, the human and the non-human. But their engagement with contemporary debates within material culture studies and beyond, will not only comment on the sorts of material sources that can contribute to geographical research but will also explore how geographers should approach these items.

Anthropologists, sociologists and design historians are presently engaged in detailed debates about what 'material cultures' are and how they should be approached (Dilnot, 1984; Bennet, 2004; Dant, 2004; Latour, 2007; Miller, 2008; Ingold, 2012). Their disagreements tend to cluster around how much emphasis should be placed on the importance of material qualities or implicit social meanings, consumption or production, and independent agency. Using material culture to tell stories about human relationships, Daniel Miller (2008) is one of the loudest voices in the 'social meanings' camp. Focusing on how objects are consumed by human societies, his discussions place agency in the hands of humans and suggest that objects only gain meaning once they are bought, used and exchanged within human relational networks. In contrast, Tim Ingold (2012) fights for the 'material qualities' corner. Contesting that material things are not produced by human imposition over raw materials, but are instead the result of relationships between human skill and material qualities, he argues that a material's qualities continue to influence a material thing's characteristics during the course of its lifespan. Redressing the imbalance of Miller's narrative, Ingold 
retrieves material agency, arguing that material qualities have just as much influence on human behavior as human behavior has on material things. As such, Ingold's approach is positioned within a broader interdisciplinary discussion about more-than-human agency, including Actor-Network Theory (ANT), Assemblage thinking (Muller and Schurr, 2016) and the interdisciplinary concept of 'new materialism' (Coole and Frost, 2010), which illustrate just some of the frameworks designed (and continual reformed) to explore the entwined nature of human and more-than-human relationships. Consequently, those keen to embrace material analysis and use it within their research can engage with a diverse range of perspectives and a heated debate about the intricacies of material approaches.

As lan Cook and Divya Tolia-Kelly (2010) have demonstrated, geography's relationship with material cultures has often been contentious. Within the sub-discipline of cultural geography, the appropriation, use and rejection of materiality has often reflected broader debates about what 'culture' and 'cultural geography' are. As early as Carl Sauer and the Berkeley School (Sauer, 1925) material cultures (most specifically the materiality of rural landscapes) were a prominent part of cultural geography: the design of historical landscapes read as illustrative of the cultural practices of the societies which used them. By the late twentieth century, a broader range of material things began to be incorporated within cultural geography, as the centrality of all cultural practices to human existence was emphasized and elitist definitions of culture were dispelled. However, reflecting contemporary cultural geography's conception of culture as socially constructed, these approaches continued to consider material things as representations (or texts) that reflected human practices (Cosgrove and Jackson, 1987). In contrast, as the twentieth century drew to an end and the early decades of the twenty-first century progressed cultural geography began to reconsider 'culture', reformulating it as much more than a representation of social practices by focusing on its affect rather than its hidden meaning (Mitchell, 1995; Cresswell, 2010). In-line with these new ideas, greater emphasis began 
to be placed on the intertwined agency of various (man-made and natural) material things within human practices. Indeed, in 2011 Divya Tolia-Kelly specifically warned against the dangers of 'surface geographies', arguing that simply describing materialities and their meanings is insufficient and it is necessary to understand their active and variable participation in a network of material and human actors.

Within this context, geographers have taken a range of different approaches to, and engaged with a vast array of material cultures. Some have demonstrated the validity of engaging with material things in geographic research by integrating analysis of material sources with information gained from written documents, fieldwork or interviews. For example, Fraser MacDonald's (2002) exploration of worship and place making in contemporary Church of Scotland communities included references to objects within a broader analysis of how practice and social relationships created religious space. Others have embraced the potential of material sources and material approaches by starting their investigations with material sources, using the unique qualities of material items to tell alternative stories. For example, lan Cook and others (2007) have followed things, writing object biographies that use specific material items to explore broader stories around consumption, the environment and cultural identity. Increasing attention has begun to be paid to the materiality of creative geographies (Hawkins et al, 2015); Amanda Rogers (2017) exploring the broad range of material things involved in theatre performance to gain insights into the multiple mutabilities of performances when they are moved through transnational spaces. Additionally, closer consideration has been paid to the 'livingness' of the material world (Wylie, 2002); Pamela Richardson-Ngwenya (2014) exploring practical methods of carrying out Sarah Whatmore's (2006) call for material approaches to the 'more-than-human' world.

Similar trends have occurred within recent historical geography. There has been a growing appreciation of the potential of material items to provide 
alternative, often more personal, insights into well-established social stories. For example, Julian Holloway (2015) integrated material analysis of Joanna Southcott's box of prophecies and more conventional historical texts to investigate historical geographies of prophecy. Similarly Briony McDonagh (2018) has used a range of (largely written) sources to approach buildings and landscapes as material things in her exploration of elite landed women in the long eighteenth century. Additionally, historical geographers have also begun to use the material archive to inspire and direct their research. Many of these approaches have focused on the consumption of material items, using them to enliven social investigations. For example, Veronica Della Dora (2011) has demonstrated the mutability of sacred space through the common practice of pilgrim cards in nineteenth-century Russian Orthodox practices and Caitlin DeSilvey (2007) has used scraps of material remnants to piece together personal insights into people's lived experiences on early-twentieth century farms in Montana. Other approaches have paid more attention to the material properties of material items, Tim Edensor (2011) exploring how the material qualities of the stone used to build St Ann's Church in Manchester has changed over time as a result of its relationships with non-human agencies like pollution, weather and animals. Similarly, an increasing amount of attention is now being paid to the production of material items in historical (and contemporary) geographies of craft and skill (Bond et al, 2013; Patchett and Mann, 2018); Merle Patchett (2016) experimentally putting herself in the position of a taxidermist's apprentice to explore how the craft of taxidermy has developed over time as it has been practiced.

However, despite historical geographers' readiness to embrace material sources and the increasingly innovative ways in which they are approaching material archives, there has been no explicit discussion about the roles, potentials and problems of using material cultures in historical geography research. Questions about what sorts of material objects historical geographers can engage with, how they can use them, and how employing material sources can contribute or detract from the development of the 
discipline have yet to be overtly raised and debated. In response, the papers in this special section directly tackle questions related to the potential benefits and difficulties of using material culture in historical geography research. Approaching historical geography from various disciplinary backgrounds, including dress history, design history, social geography and technology studies, each paper uses a specific case study from a range of geographical and temporal contexts to address broader issues about historical geographers' use of material culture. Despite the variety of the specific material items they discuss and the different approaches they use to engage with the materiality of their empirical attention, the papers make a collective contribution to discussions about the place of material culture in geographical methodologies.

Loosely arranged according to the chronological order of each paper's subject matter, this special section begins with Hannah Stockton's exploration of the materiality of the River Thames between 1730 and 1830 . Focusing on the construction of bridges across the river during this period, Stockton reflects on how the river was a coproduced space created by the entangled agency of human and non-human forces. Therefore, this paper provides a concrete example of the necessity of understanding the variability of spaces through a combined consideration of social practices, material features and individual human actions and responses. Secondly, my own paper engages with ideas about the becoming nature of material things, reflecting on how such an approach to the material archive provides a possible means of gaining insights into individuals' everyday experiences of nineteenth-century Methodism. As such, my paper explores how material sources and approaches can provide a useful tool for historical geographers interested in the more mundane aspects of historical everyday life. While such everyday subjects are presently being increasingly explored within contemporary geographical research, they have consistently been much more difficult for historical geographers - constrained by uneven patterns of (often official) archival survival - to uncover. Continuing with a similar 
historical interest in geographies of everyday practices, Elizabeth Haines reflects on the extent to which her own archival practice could be considered a re-enactment of, and therefore a point of entry into, the everyday life of black African clerks in Zambia's early twentieth-century colonial offices. Experimenting with the possibilities of 'enlivening' or 'animating' the past and sensitively engaging with the ethical issues such an approach poses, Haines makes an important contribution to debates about the place of performative research in historical geography, particularly raising specific questions about how material things are part of this process. In this special section's fourth paper, Bethan Bide takes a close and intimate approach to clothes made in post-war 1940s London. Thinking about the processes undertaken to make these garments, Bide reveals previously untold stories about the networks of makers involved in the creation of these objects and the individual creativity they were able to exercise in the production process. As such, she suggests the possibilities that object-orientated research could have for further complicating established geographical conceptions of global fashion cities. Finally, focusing on the display of British Rail's 1972 'Advanced Passenger Train Experimental' (APT-E) in the National Railway Museum, Paul Wright reflects on the tensions present when statically displaying objects designed to be mobile. Therefore, Wright explicitly engages with a theme implied throughout this special section, foregrounding the museum and archival context in which many of the material sources discussed by various contributors. By doing so with reference to Gosz's understanding of duration, he demonstrates how these objects' current contexts play an important role in informing how geographers reflect on their historical meanings and identities, but more importantly highlights how (historical) geographers necessarily need to 'unsettle' these established contexts and reconsider how they think about material things once they are no longer used.

Consequently, this special section's papers demonstrate the potential of material sources to highlight alternative narratives. Through their use of material sources they not only engage with conventional geographical 
themes such as the landscape, imperialism, transport, technology and the 'museum space' from alternative angles, but also introduce less familiar stories, such as clothing, religious non-conformity and administrative paperwork into the geographical debate. More specifically, many of these papers contribute to geography's growing interest in the everyday, particularly historical geographies of the everyday, by illustrating how material approaches offer a range of options to help overcome the difficulties of gaining insights into mundane experiences rarely recorded within the written archive. These papers also demonstrate the potential of giving attention to the 'becoming' nature of material things, illustrating how thinking about the life cycle of material sources can facilitate interesting insights into historical practices. Therefore, these papers contribute to contemporary debates about the merits of studying the material properties or social meanings of materials and highlight the relative usefulness of both approaches when practically applied to empirical research. Finally, each of the papers deal with the problems of archival survival posed by each empirical project. Discussing the difficulties, but also the opportunities, of carrying out material research into historical moments rarely faithfully represented in the material archival, these papers make an important contribution to discussions about the legitimacy of material methodologies.

It is hoped that the range of these papers' empirical subject matters and theoretical approaches will demonstrate the huge scope of material possibilities available to geographers (historical or not). Although united by their methodological considerations, the papers in this special section do not aim to create a 'how-to' guide to materially focused historical geographies, but rather encourage further discussion about the relationship between material culture and geographical research.

\section{Acknowledgements}


This special section developed from several sessions exploring the use of material culture in historical geography research at the 2015 International Conference of Historical Geographers in London. Besides the papers included here, contributions were made to these sessions by Sam Barton, Alison L Goodrum, Alison Hess, James Kneale and Merle Patchett. Thanks are due to Peter Kraftl, James Kneale and all the contributors to this special section for their comments on this introduction.

\section{Notes}

Bennet, Jane. (2004). The Force of Things: steps towards an ecology in matter. Political Theory, 32.3, 347-372.

Bond, Steven, DeSilvey, Caitlin, Ryan, James R. (2013). Visible Mending: Everyday Repairs in the South West. Axminster: Uniform Books.

Coole, Diana and Frost, Samatha. (eds) (2010). New Materialisms: Ontology, Agency, and Politic. Durham and London: Duke University Press.

Cook, lan and Harrison, Michelle. (2007). Follow the Thing: "West Indian Hot Pepper Sauce." Space and Culture, 10.1, 40-63.

Cook, lan and Tolia-Kelly, Divya P. (2010). Material Geographies. Mary C. Beaudry and Dan Hicks (eds.), The Oxford Handbook of Material Culture Studies (pp.99-122). Oxford: Oxford University Press.

Cosgrove, Denis and Jackson, Peter. (1987). New directions in cultural geography. Area, 19.2, 95-101.

Cresswell, Tim. (2010). New cultural geography - an unfinished project?. Cultural Geographies, 17.2, 169-174.

Dant, Tim. (2004). Materiality and Society. New York: Open University Press.

Della Dora, Veronica. (2011). Circulating Sacred Place: Fin-de siècle Russian Cards of Mount Athos as Travelling Object-Icons. In Catherine Brace, Adrian Bailey, Sean Carter, David Harvey and Nicola Thomas (eds.), Emerging Geographies of Belief (pp.168-192). Newcastle Upon Tyne: Cambridge Scholars Publishing.

DeSilvey, Caitlin. (2007). Salvage Memory: Constellating Material Histories on a Hardscrabble Homestead. Cultural Geographies, 14.3, 401-24. 
Dilnot, Clive. (1984). The State of Design History, Part 1: Mapping the Field. Design Issues, 1.1, 4-23.

Edensor, T. (2011). Entangled Agencies, Material Networks and Repair in a Building Assemblage: the mutable stone of St Ann's Church Manchester. Transactions of the Institute of British Geographers, 36, 238-252.

Hawkins, Harriet, Marston Sallie A, Ingram, Mrill and Staughan, Elizabeth. (2015). The Arts of socio-ecological transformation. Annals of the Association of American Geographers, 105.2, 331-341.

Holloway, Julian. (2015). Sealing future geographies: religious prophecy and the case of Joanna Southcott. Transaction of the Institute of British Geographers, 40.2, 180-191.

Ingold, Tim. (2012). Towards an Ecology of Materials. Annual Review of Anthropology, 41, 427-442.

Latour, Bruno. (2007). Reassembling the Social: An Introduction to ActorNetwork-Theory, 63-86. Oxford: Oxford University Press.

MacDonald, Fraser. (2002). Towards a Spatial Theory of Worship; Some Observations from Presbyterian Scotland. Social and Cultural Geography, 3.1, 61-80.

McDonagh, Briony. (2018). Elite Women and the Agricultural Landscape, 1700-1830. London and New York: Routledge.

Miller, Daniel. (2008). The Comfort of Things. Cambridge and Malden: Polity Press.

Mitchell, Don. (1995). There's No Such Thing as Culture: Towards a Reconceptualisation of the Idea of Culture in Geography. Transactions of the Institute of British Geographers, 20.1, 102-116.

Muller, Martin and Schurr, Carolin. (2016). Assemblage Thinking and ActorNetwork Theory: conjunctions, disjunctions, cross-fertilisations. Transactions of the Institute of British Geographers. 41.3, 217-229.

Patchett, Merle. (2016). The taxidermist's apprentice: stitching together the past and present of a craft practice. Cultural Geographies, 23.3, 401-419.

Patchett, Merle and Mann, Joanna. (2018) Special Issue: Geographies of Skilled Practice. Cultural Geographies, 25.1.

Richardson-Ngwenya, Pamela. (2014). Performing a more-than-human material imagination during fieldwork: muddy boots, diarizing and putting vitalism on video. Cultural Geographies, 21.2, 293-99. 
Rogers, Amanda. (2017). Material Migrations of Performance. Area, 49.4, 495-502.

Sauer, Carl. (1925). The Morphology of Landscape. Berkeley: University of California Press.

Tolia-Kelly, Divya P. (2011). The geographies of cultural geography III: Material geographies, vibrant mater and risking surface geographies. Progress in Human Geography, 37.1, 153-160.

Whatmore, Sarah. (2006). Materialist returns: practising cultural geography in and for a more-than-human world. Cultural Geographies, 13.4, 600-609.

Wylie, John. (2002). An essay on ascending Glastonbury Tor. Geoforum, 33, 441-454. 